\title{
DNA Damage Detection after Chronic Exposure and Radio-adaptive Response of Naturally Occurring Radioactive Materials (NORM)
}

\author{
S. M. El-Marakby ${ }^{\left[1^{*}\right],}$ M. H. Abdelgawad ${ }^{[2]}$, M. M. Awad ${ }^{[2]}$, K. M. Eraba ${ }^{[2]}$, O. S. Desouky ${ }^{[1]}$ \\ ${ }^{(1)}$ Biophysics lab, Radiation Physics Department, National Center of Radiation Research and Technology (NCRRT), Egyptian Atomic \\ Energy Authority (EAEA), Cairo, Egypt \\ ${ }^{(2)}$ Physics Department, Faculty of Science, Al-Azhar University, Cairo, Egypt
}

\begin{tabular}{|c|c|}
\hline ARTICLE INFO & ABSTRACT \\
\hline Article history: & \multirow{11}{*}{$\begin{array}{l}\text { The objective of the present study is to understand the effect of chronic low-dose } \\
\text { radiation that induces in vivo radio-adaptive response. The animals were exposed } \\
\text { chronically to naturally occring radioactive materials (NORM) for one and two months } \\
\text { which correspond to } 10 \& 20 \mathrm{mSv} \text { which are comparable to the reality of areas with high } \\
\text { background natural radiation (HBNR). Radioactivity assessment of samples was } \\
\text { performed using a high purity germanium } \gamma \text {-ray spectrometer. The study to understand } \\
\text { the radio-adaptive response was conducted via exposing the experimental animals to a } \\
\text { challenge dose of } 2 \mathrm{~Gy} \text {, after continuous exposure to } 10 \& 20 \mathrm{mSv} \text {. Comet assay was } \\
\text { performed in addition to some of antioxidant enzymes concentrations (superoxide } \\
\text { dismutase (SOD), catalyze enzyme (CAT), reduced and oxidized glutathione (GSH). } \\
\text { Chronic exposure to } 10 \text { and } 20 \mathrm{mSv} \text { showed DNA damage as a significant elevation in } \\
\text { Comet assay parameters. In addition, the results of the present work showed a low } \\
\text { production of antioxidant enzymes CAT, SOD \& GSH in both chronic exposures (10 \& } \\
20 \text { mSv and challange dose } 2 \mathrm{~Gy} \text { ). The exposure to } 20 \mathrm{mSv} \text { before } 2 \mathrm{~Gy} \text { gamma rays } \\
\text { resulted in an enhancement of the antioxidant enzymes accompanied with a decrease in } \\
\text { free radicals which represent an adaptive response. It can be said that for low radiation } \\
\text { doses, which are less than } 100 \mathrm{mSv} \text {, their effects differ from high doses, so that it can be } \\
\text { said that the body has an adaptive response and the application of the linear non- } \\
\text { threshold model must be reviewed for these doses. }\end{array}$} \\
\hline Received: $15^{\text {th }}$ Feb. 2021 & \\
\hline Accepted: $11^{\text {th }}$ Apr. 2021 & \\
\hline Keywords: & \\
\hline Chronic exposure, & \\
\hline Naturally Occurring & \\
\hline Radioactive Materials, & \\
\hline & \\
\hline DNA damage, & \\
\hline LNT. & \\
\hline & \\
\hline
\end{tabular}

\section{INTRODUCTION}

Low level of ionizing radiation (IR) comes from natural and man-made sources, both of them are commonly human exposure routes. These include medical (radio-therapeutic and diagnostic) and occupational exposures. Due to the existence of normally occurring radioactive materials (NORMs), there are many areas in the world where the background radiation is high. These high background natural radiation (HBNR) regions can be categorized into four levels, based on the annual effective doses of the inhabitants, as follows: low region below $5 \mathrm{mSv} / \mathrm{y}$ (standard level less than $1.5 \mathrm{mSv} / \mathrm{y})$, average level $(5-20 \mathrm{mSv} / \mathrm{y})$, high (20-50 $\mathrm{mSv} / \mathrm{y}$ ); and very high more than $50 \mathrm{mSv} / \mathrm{y}$ ) [1,2].

Geological formations such as soils, rocks, water, sediments, air, and building materials are the main sources of the NORM in the earth's environment. The naturally occurring radioactive isotopes $\left({ }^{238} \mathrm{U}\right.$ and $\left.{ }^{232} \mathrm{Th}\right)$ and their descendants, as well as ${ }^{40} \mathrm{~K}$ represent around $87 \%$ of human radiation doses $[3,4]$.Chronic exposures to natural radioactive materials have severe health effects such as lung cancer and leukemia [5].

Certain molecular processes have been suggested to be induced after exposure to low radiation doses, which are dissimilar from those induced by high dose radiation [6]. These processes originated in order to be protective as assessed by several biological endpoints [7]. The adaptive radiation response is a method of counteract the challenging dose by low-dose exposure (priming dose), thereby noticeably reducing its adverse effects. Radiation-induced DNA damage is repaired by various DNA repair pathways in human cells depending on the 
form of lesion [8]. Radio-adaptive responses were dependent on the adapting dose, dose rate, expression time, culture conditions and stage of the cell cycle [9]. Chronic 10 cGy gamma-radiation exposure to mouse embryo fibroblasts protected the cells through a subsequent high acute radiation exposure dose against neoplastic transformation [10].

A previous study concluded that the malignancy rate among the population dwelling in apartments in Taiwan who were exposed to low dose radiation (LDR) from contaminated structure materials [11, 12] has shown a lower overall cancer occurrence in the irradiated group in comparison to an age-matched control group [13].

On the molecular level, a number of studies have been carried out on stimulated DNA repair mechanisms, in both animals and humans cells. It was shown that a lower occurrence of both double and single strand breaks was induced by a 1 Gy challenge dose in lymphocytes exposed to a prime dose of $20 \mathrm{mGy}$ after the initial radiation exposure by 9 and 30 hours [14-15].

There are three major cellular ionizing radiation defense systems that engage radio-adaptive response (1) protection against reactive oxygen species (ROS) by antioxidant molecules (such as glutathione) and detoxifying enzymes (such as catalase and superoxide dismutase); (2) DNA repair, in particular for double-strand breaks, that disappears at doses higher than $0.5 \mathrm{~Gy}$; (3) and removal of genomically injured cells at doses as low as a few $\mathrm{mSv}$ through immune defenses and apoptosis. It is known that the radiation hormesis reaction is associated with increased lifespan and decreased mutations [16,17]. Regardless of wide data on radiation risks, the health effects of chronic low-level radiation exposure are still inadequately understood.

The aim of the current study is focused on the chronic exposure of low radiation levels $10 \& 20 \mathrm{mSv}$ which are comparable to the reality of areas with a high background natural radiation (HBNR). In addition, a dose of $20 \mathrm{mSv}$ corresponds to the annual dose limit for occupational exposure. At the same time, the study was conducted to understand the radio-adaptive response by exposing the experimental animals to 2 Gy after continuous exposure to $10 \& 20 \mathrm{mSv}$.

\section{Materials and Methods}

\subsection{Radiometric Analysis of TE-NORM Samples}

8 samples of Technologically enhanced NORM (TENORM) waste from the oil \& gas industry were packaged in plastic containers $(0.5 \mathrm{~kg}$ each $)$, sealed and stored for 4 weeks in order to create a secular equilibrium between the natural radionuclides and their respective progenies. A High Purity Germanium Detector was used to measure gamma-ray from the NORM samples.

The activity concentrations of ${ }^{238} \mathrm{U},{ }^{232} \mathrm{Th}$ and ${ }^{40} \mathrm{~K}$ were calculated using spectrum software program (Genie 2000). Figure (1) shows a typical gamma ray spectrum for a NORM sample.

The activity of ${ }^{226} \mathrm{Ra}$ and ${ }^{232} \mathrm{Th}$ was determined by their decay products ${ }^{214} \mathrm{Bi}(609 \mathrm{keV}$ and $1120 \mathrm{keV})$, ${ }^{214} \mathrm{~Pb}\left(295 \mathrm{keV}\right.$ and $352 \mathrm{keV}$ ) and ${ }^{228} \mathrm{Ac}(338 \mathrm{keV}$ and $911 \mathrm{keV}$ ) respectively, while the activity of ${ }^{40} \mathrm{~K}$ was determined from its $1460.8 \mathrm{keV}$ gamma energy. The measuring counting time was $4 \mathrm{hrs}$, the natural background radiation was subtracted from the accumulated spectrum [18].

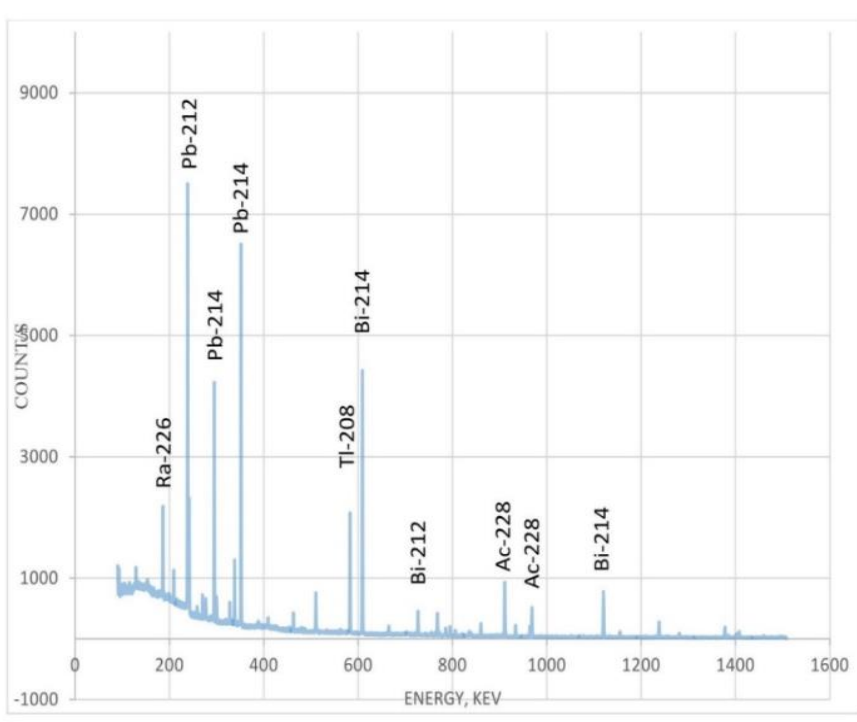

Fig. (1) Typical gamma ray spectrum for a NORM sample

\subsection{Animal preparation}

36 adult male albino rats $(220 \pm 10 \mathrm{~g})$ were housed in plastic cages at ambient temperature, humidity and regulated light (12-h day/night cycle). The animals were randomly divided into six groups, each one consisting of 6 rats; they were feed with balanced normal food. Rats were anaesthetized with diethyl ether in each group. Blood samples were obtained through eye puncture; EDTA (ethylene di-amine tetra-acetic acid) was used to prevent clotting. The current study was conducted in compliance with the IACUC (The Institutional Animal Care and Use Committee) statement for the use of animals in research and teaching by the local ethical committee of AUHA (Al-azhar University Housing Animals). 


\subsection{Animal Irradiation}

The experimental animals were chronically exposed to natural radioactive materials for a period of one and two months which approximately equivalent to absorbed dose $10 \& 20 \mathrm{mSv}$ as calculated from the activity of the naturally occurring radioactive materials $[19] .{ }^{137} \mathrm{Cs}$ source, at a dose rate $0.695 \mathrm{~Gy} /$ minute, at the National Center for Radiation Research and technologies, Egyptian Atomic Energy Authority, EAEA was used to deliver the challenge dose of 2 Gy to the experimental animals.

\subsection{Comet assay}

The method described by Singh et al. [20] was used with minor modifications to detect the alkaline Comet assay. In brief, about $1 \times 10^{4}$ cells were mixed with low melting agarose (Solarbio, Beijing, China) and spread on microscope slides. The cells were lysed at $\mathrm{pH} 10$ and DNA was unwound for $20 \mathrm{~min}$ in an alkaline buffer $(\mathrm{pH}$ 13), followed by electrophoresis $(25 \mathrm{~V}, 300 \mathrm{~mA})$ for 30 min. The cells were neutralized $(5 \mathrm{mg} / \mathrm{L}$, Sigma, St. Louis, MO) and stained with ethidium bromide. All coded slides for each exposure condition were examined using fluorescence microscope (Nikon, Tokyo, Japan) equipped with CASP software (CASP Lab, Poland). The Comet tail length (TL) was measured by examining 50 Comet in micrometers. The Comet tail moment (TM) was calculated from the Comet tail length multiplied by DNA percentage in Comet tail [22]. Data were decoded after achievement of all microscopic analyses.

\subsection{Biochemical analysis}

The biochemical analysis was carried by centrifugation the sera for 10 minutes at $3000 \mathrm{rpm}$ and stored in a refrigerator at $-20^{\circ} \mathrm{C}$ until being used. The technique of Ahmed et al. [23] was used to measure the reduced glutathione (GSH) content, while the catalase activity was measured according to the method of Sinha [24] by measuring the catalytic reduction of hydrogen peroxide. The superoxide dismutase activity was measured utilizing the method of Minami and Yoshikawa [25].

\subsection{Statistical analysis}

The data analysis and comparison was performed by ANOVA statistical analysis using SPSS 23 program. Statistical significance value was set at $(\mathrm{p}<0.05)$ and the results are represented as mean \pm S.D.

\section{RESULTS}

\subsection{Evaluation of absorbed dose \& annual effective dose}

The radiation damage to tissue and/or organs depends on the dose of radiation received or the absorbed dose. The absorbed dose of radiation is the energy imparted per unit mass of the irradiated material. By applying the conversion factors $0.462,0.604$ and 0.0417 for uranium, thorium and potassium, the activity concentrations of ${ }^{238} \mathrm{U},{ }^{232} \mathrm{Th}$, and ${ }^{40} \mathrm{~K}$ are converted into doses using the following equation [19]:

$$
\mathrm{D}\left(\mathrm{nGyh}^{-1}\right)=0.462 \mathrm{~A}_{\mathrm{U}}+0.604 \mathrm{~A}_{\mathrm{Th}}+0.041 \mathrm{~A}_{\mathrm{k}}----- \text { (1) }
$$

Where $A_{k}, A_{U}$ and $A_{T h}$ are the activity concentrations of ${ }^{40} \mathrm{~K},{ }^{238} \mathrm{U}$ and ${ }^{232} \mathrm{Th}$ in $\mathrm{Bqkg}^{-1}$ respectively. It is recommended that the acceptable total absorbed dose rate by the workers in areas containing gamma radiations from $^{238} \mathrm{U}$ and ${ }^{232} \mathrm{Th}$ series and their respective decay progenies, as well as ${ }^{40} \mathrm{~K}$, must not exceed $0.059 \mathrm{mGyh}^{-1}[19]$.

Human exposure from external sources is mostly induced by gamma radiation from radionuclides in the ${ }^{238} \mathrm{U}$ and ${ }^{232} \mathrm{Th}$ series and from ${ }^{40} \mathrm{~K}$ present in all soils. Naturally occurring primordial radionuclides are present in different degrees in all media in the environment, including the human body. The annual effective dose equivalent in $\mathrm{mSvy}^{-1}(\mathrm{AEDE}$ in Eq. 2) is obtained by applying a dose conversion factor of $0.7 \mathrm{~Sv} / \mathrm{Gy}$ to the absorbed dose rate " $\mathrm{D}$ " $1 \mathrm{~m}$ aboveground:

$\operatorname{AEDE}(\mathrm{mSv} / \mathrm{y})=\mathrm{D}(\mathrm{nGy} / \mathrm{h}) \times 8760 \mathrm{~h} / \mathrm{y} \times 0.7 \mathrm{~Sv} / \mathrm{Gy} \quad---(\mathbf{2})$

The activity of ${ }^{226} \mathrm{Ra},{ }^{232} \mathrm{Th}$ and ${ }^{40} \mathrm{~K}$, the absorbed dose and annual effective dose are given in table (1).

Table (1): Results of activity concentrations $(\mathrm{Bq} / \mathrm{Kg})$ and the radiation exposure dose

\begin{tabular}{cccccc}
\hline \multirow{2}{*}{ Sample } & ${ }^{40} \mathbf{K}$ & ${ }^{232} \mathbf{T h}$ & ${ }^{226} \mathbf{R a}$ & $\mathbf{D}$ & AEDE \\
\cline { 2 - 6 } & $\mathbf{B q ~ K g}^{-1}$ & $\mathbf{B q ~ K g}^{-1}$ & $\mathbf{B q ~ K g}^{-1}$ & $(\mu \mathbf{G y} / \mathbf{h})$ & $(\mathbf{m S v} / \mathbf{y})$ \\
\hline 1 & $4.42 \mathrm{E}+03$ & $5.40 \mathrm{E}+04$ & $3.08 \mathrm{E}+04$ & $4.60 \mathrm{E}+01$ & $5.64 \mathrm{E}+01$ \\
2 & $4.84 \mathrm{E}+03$ & $5.64 \mathrm{E}+04$ & $1.19 \mathrm{E}+05$ & $8.58 \mathrm{E}+01$ & $1.05 \mathrm{E}+02$ \\
3 & $4.36 \mathrm{E}+03$ & $5.10 \mathrm{E}+04$ & $1.09 \mathrm{E}+05$ & $7.84 \mathrm{E}+01$ & $9.62 \mathrm{E}+01$ \\
4 & $4.87 \mathrm{E}+03$ & $5.89 \mathrm{E}+04$ & $1.18 \mathrm{E}+05$ & $8.71 \mathrm{E}+01$ & $1.07 \mathrm{E}+02$ \\
5 & $4.59 \mathrm{E}+03$ & $5.52 \mathrm{E}+04$ & $1.17 \mathrm{E}+05$ & $8.43 \mathrm{E}+01$ & $1.03 \mathrm{E}+02$ \\
6 & $4.24 \mathrm{E}+03$ & $5.01 \mathrm{E}+04$ & $1.03 \mathrm{E}+05$ & $7.52 \mathrm{E}+01$ & $9.22 \mathrm{E}+01$ \\
7 & $4.86 \mathrm{E}+03$ & $5.73 \mathrm{E}+04$ & $1.23 \mathrm{E}+05$ & $8.81 \mathrm{E}+01$ & $1.08 \mathrm{E}+02$ \\
8 & $4.55 \mathrm{E}+03$ & $5.56 \mathrm{E}+04$ & $1.16 \mathrm{E}+05$ & $8.42 \mathrm{E}+01$ & $1.03 \mathrm{E}+02$ \\
\hline AVG. & 4591.13 & 54815.00 & 104597.02 & 78.63 & 96.43 \\
\hline S.D. & 247.04 & 3001.53 & 30441.22 & 13.91 & 17.06 \\
\hline
\end{tabular}




\subsection{Effect of chronic exposure}

The detection of DNA damage and repair was carried out by a sensitive Genotoxicity test Comet assay. To evaluate the extent of DNA damage at the single-cell level, the following parameters were calculated: 1) Comet assay (CA) that means total distance between the beginning of head to the end of tail. 2) Tail length (TL) or tail extent exhibits the length of the tail. 3) DNA percentage in tail $(\%$ DNA) $=(100-$ DNA of head $)$. 4) Tail Moment $(\mathrm{TM})=($ tail length $* \%$ DNA in tail $) / 100)$
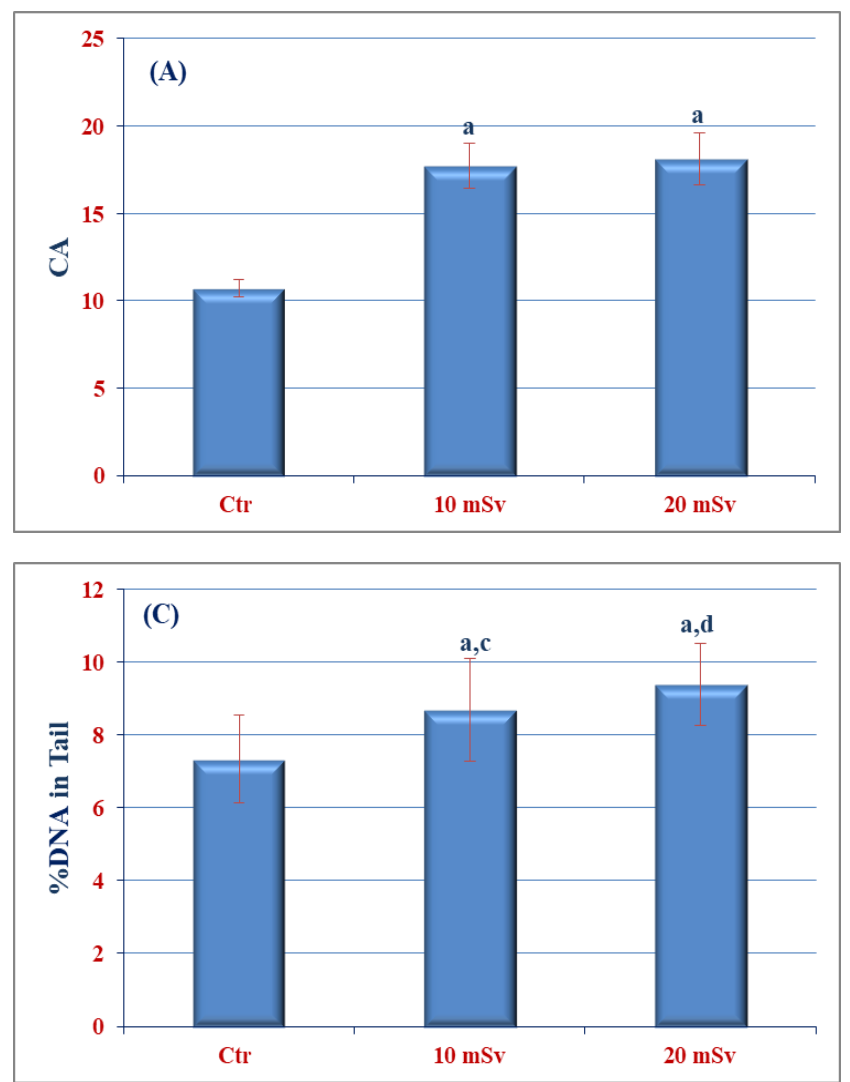

Olive Tail Moment $($ OTM $)=(($ tail mean- head mean $) *$ $\%$ DNA in tail) $/ 100$.

The present study showed that exposure to $10 \& 20$ $\mathrm{mSv}$ induced an increase in all Comet Assay parameters namely, Tail Length, \% of DNA in tail, Tail Moment, and Olive Tail Moment. The CometComet assay parameters were increased significantly as follows: CA from 10.7 to $18.1 \%$, TL from 4.3 to $5.05 \mu \mathrm{m}$, \%DNA from 7.34 to 9.4 , TM from 0.32 to $0.478 \mu \mathrm{m}$ and OTM from 0.676 to 0.96 respectively (Fig.2).
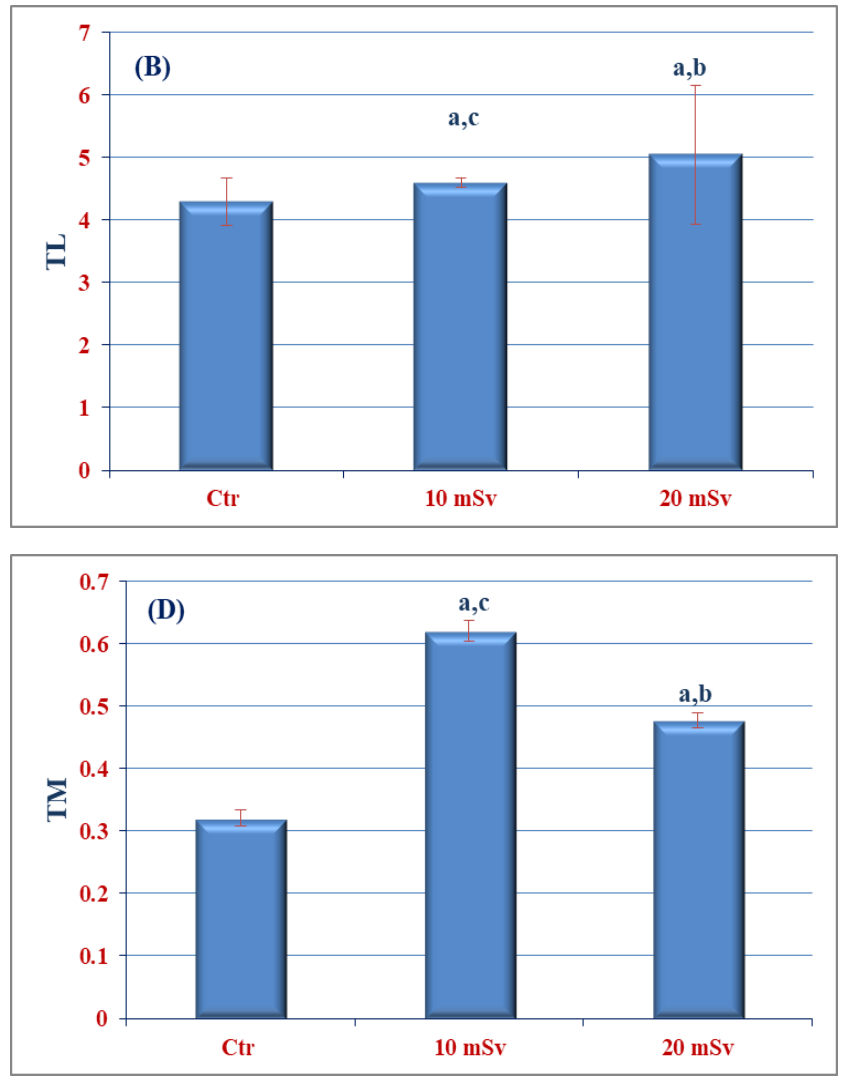

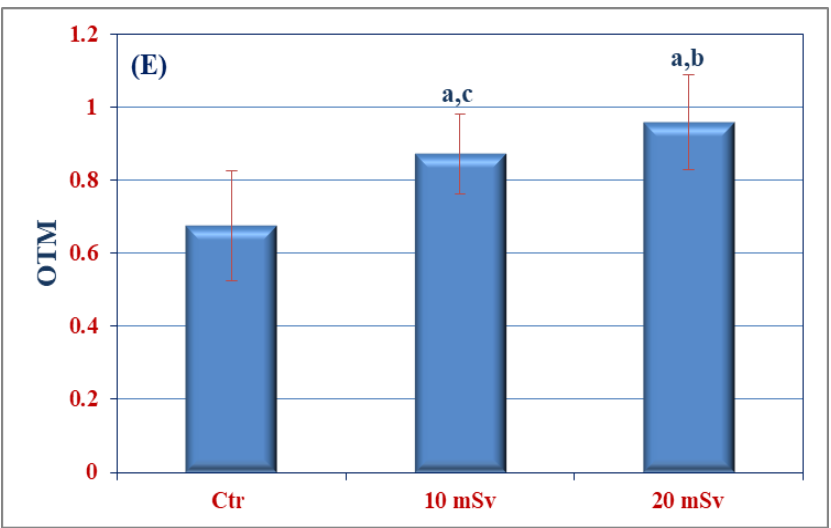

Fig. (2): Comet Assay indices (Comet \%(A), Tail length(B), \%DNA(C), Tail moment(D) and OTM(E)) of control and 10 \& $20 \mathrm{mSv}$.

Each value represents the mean of 6 records \pm S.E.,

(a) Significant difference versus control group at $\mathrm{P}<0.05$.,

(b) Significant difference versus $10 \mathrm{mSv}$ group at $\mathrm{P}<0.05$.,

(c) Significant difference versus $20 \mathrm{mSv}$ group at $\mathrm{P}<0.05$. 
Figure (3) shows the changes in the antioxidant Enzymes levels (CAT, SOD, GSH) induced by 10 \& 20 $\mathrm{mSv}$ absorbed dose. Catalase activity showed a significant decrease after $10 \mathrm{mSv}$ and non-significant change for $20 \mathrm{mSv}$ (Fig. 3B). However, SOD activity showed a significant increase for $10 \mathrm{mSv}$ and a significant decrease for $20 \mathrm{mSv}$ when compared to the control group (Fig.3A). However, GSH showed a significant decrease by $31 \%$ for $10 \& 20 \mathrm{mSv}$, (Fig.3C).

\subsection{Radio-adaptive response}

All Comet assay parameters showed significant increases after exposure to $2 \mathrm{~Sv}$ and $10 \mathrm{mSv}$ followed by $2 \mathrm{~Sv}$, when compared to the control group (Fig.4). Exposure to $20 \mathrm{mSv}$ followed by $2 \mathrm{~Sv}$ showed an insignificant change, when compared to the control group, while it showed a significant decrease, when compared to the $2 \mathrm{~Sv}$ as shown in Figure (4).

Figure (5) shows that the antioxidant parameters CAT, SOD and GSH. SOD concentration significantly decreased in all irradiated groups: $2 \mathrm{~Sv}$ and $10 \& 20 \mathrm{mSv}$ followed by $2 \mathrm{~Sv}$, (Fig 5A). The most prominent result was the decrease at the exposure to $20 \mathrm{mSv}$ followed by $2 \mathrm{~Sv}$, which decreased by $20 \%$ as compared to the control group. However, CAT almost showed no change either at a dose of $2 \mathrm{~Sv}$ or for $10 \& 20 \mathrm{mSv}$ followed by $2 \mathrm{~Sv}$, (Fig 5B). At the same time, the GSH concentration decreased significantly for groups: $2 \mathrm{~Sv}$ and for $10 \& 20$ $\mathrm{mSv}$ followed by $2 \mathrm{~Sv}$ (Fig. 5C).
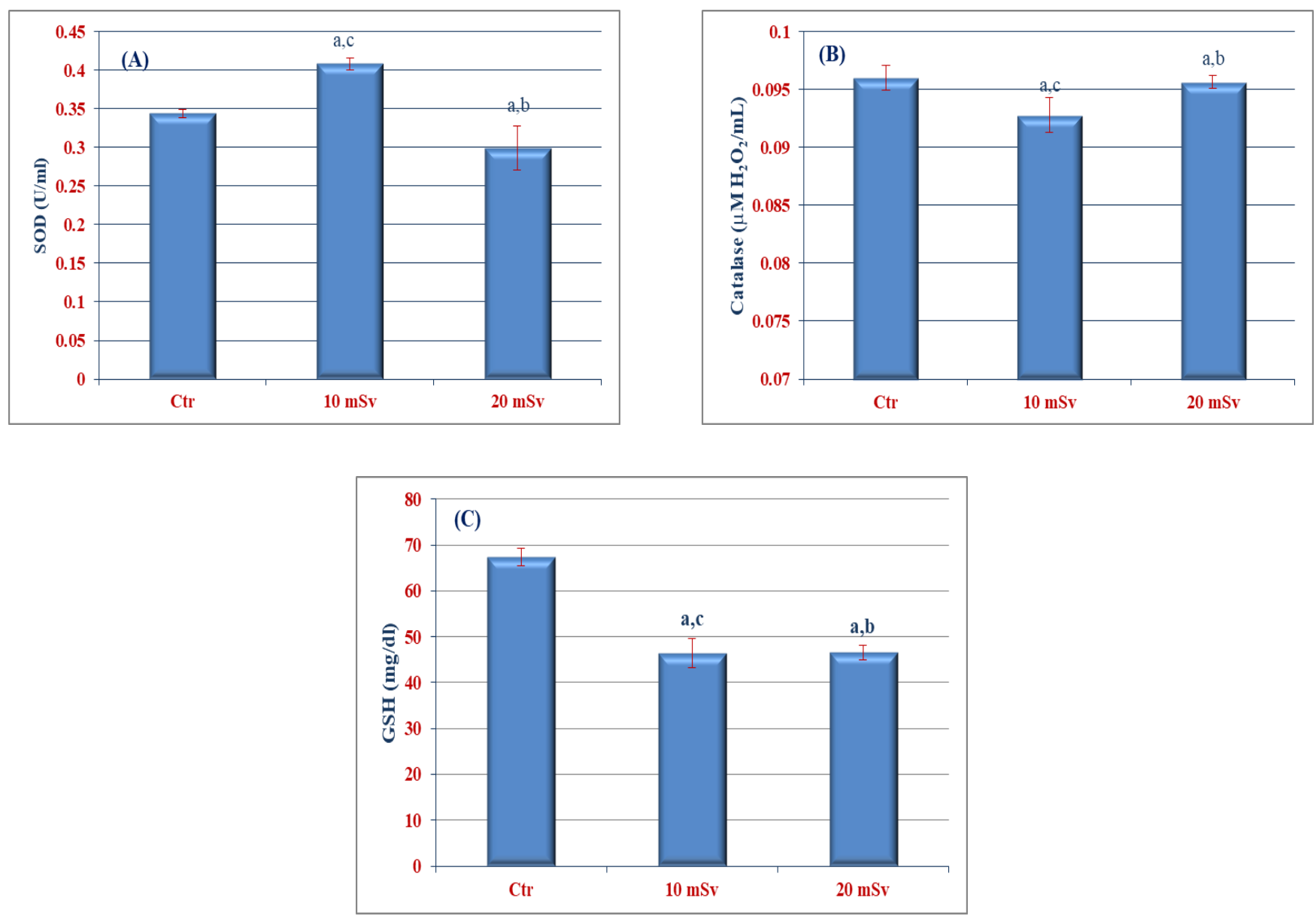

Fig. (3): The antioxidant enzymes (SOD (A), catalase activity (B) and GSH (C) of control and TE-NORM groups

Each value represents the mean of 6 records \pm S.E.,

(a) Significant difference versus control group at $\mathrm{P}<0.05$.,

(b) Significant difference versus $10 \mathrm{mSv}$ group at $P<0.05$.,

(c) Significant difference versus $20 \mathrm{mSv}$ group at $\mathrm{P}<0.05$. 

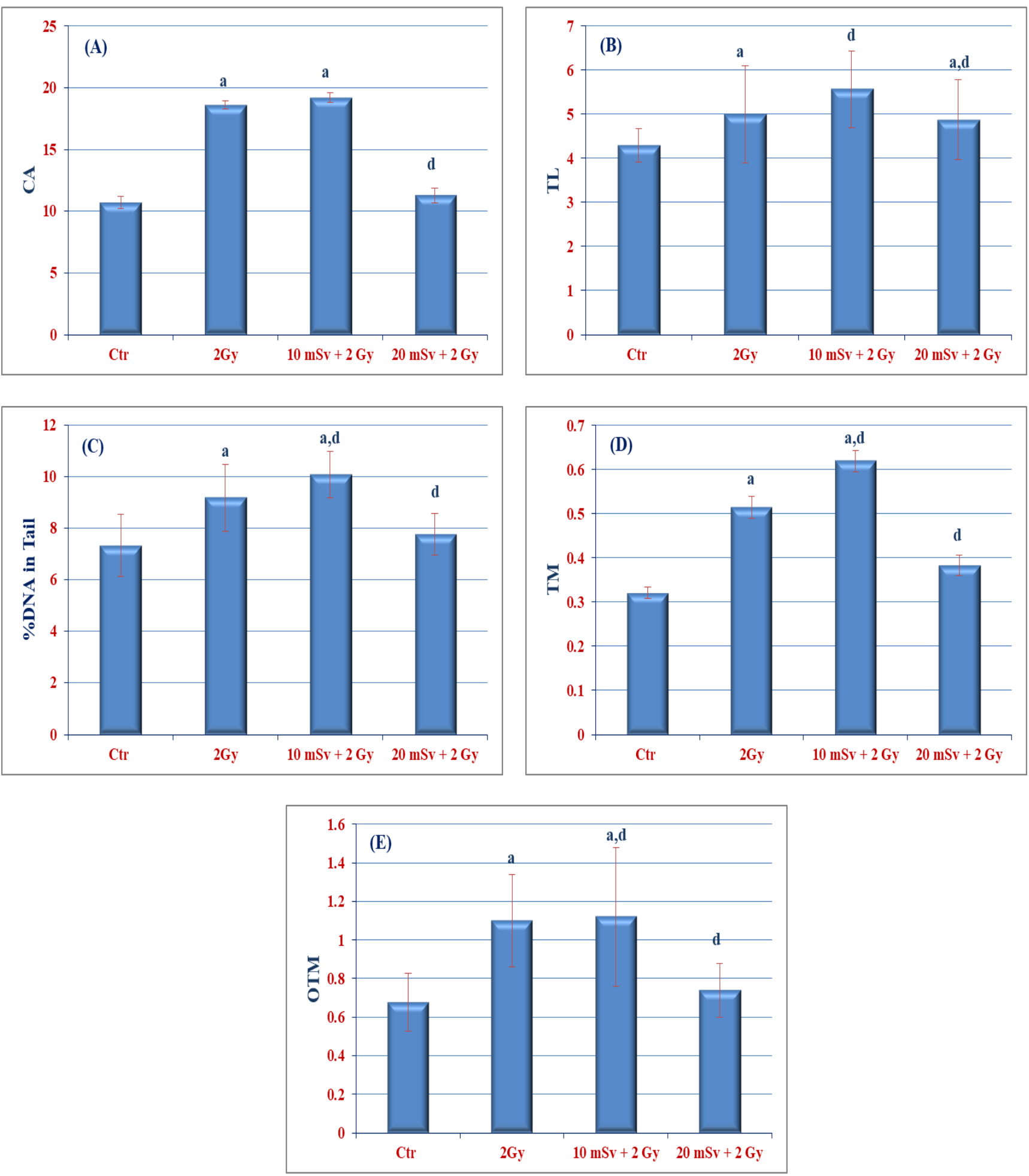

Fig. (4): Comet Assay indices (Comet \%(A), Tail length(B), \%DNA(C), Tail moment(D) and OTM(E)) of control, $2 S v$ and 10 \&20 $\mathrm{mSv}$ followed by $2 \mathrm{~Sv}$

Each value represents the mean of 6 records \pm S.E.

(a) Significant difference versus control group at $\mathrm{P}<0.05$

(d) Significant difference versus $2 \mathrm{~Sv}$ group at $\mathrm{P}<0.05$ 

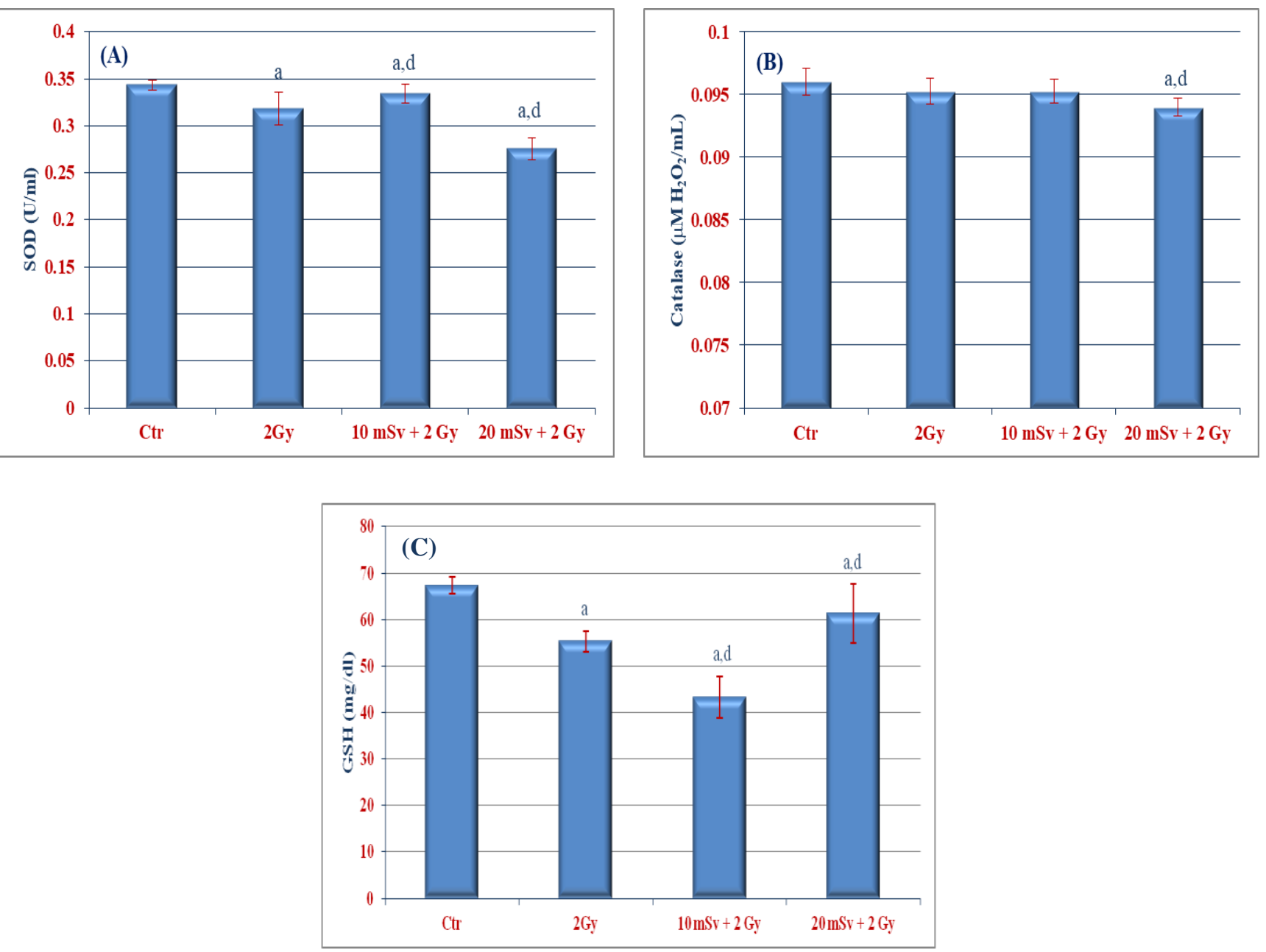

Fig. (5): The antioxidant enzymes (SOD (A), Catalase activity (B) and GSH (C) of control $2 \mathrm{~Sv}$ and 10 \& $20 \mathrm{mSv}$ followed by $2 \mathrm{~Sv}$ groups

Each value represents the mean of 6 records \pm S.E.

(a) Significant difference versus control group at $\mathrm{P}<0.05$

(d) Significant difference versus $2 \mathrm{~Sv}$ group at $\mathrm{P}<0.05$

\section{DISCUSSION}

In recent years, the effect of ionizing radiation on cell and DNA has been very well understood. On the other hand, studies have been conducted using cell strains and mice, using acute or multiple doses of radiation. Therefore, the prolonged exposure to chronically low-dose ionizing radiation from normal cells and species is relatively little understood [26]. The biological effects of prolonged exposure to low doses of natural radiation are another field not thoroughly researched. It comes mainly from natural sources including radon, earthly and cosmic radiation that penetrate the outer atmosphere of the earth. The average human exposure will be around $2.4 \mathrm{mSv}$ per year [27], but in many geographic regions all over the world this dose rises over ten times [28]. The International
Commission of Radiological Protection (ICRP) Publication 103 [29] recommended the dose limit for occupational exposure in planned situations of $20 \mathrm{mSvy}^{-1}$ averaged over 5 year $(100 \mathrm{mSv}$ in 5 years $)$ with an effective dose not more than $50 \mathrm{mSv} / \mathrm{y}$.

This study comes within the framework of an attempt to answer the question posed, whether chronic exposure to low doses of natural radiation may cause harm to residents of areas with high radiation background? or could this exposure be beneficial to these populations and causes what is called radioadaptive response? This is an open scientific controversy, and many scientific schools try to answer this question, taking into account the international rules for radiation protection that depend on Linear no-Threshold (LNT) model, which is based on the fact 
that there is a linear relationship between dose and risk. It considered that any radiation dose, even if it is a low one, has a harmful effect [17]. The DNA damage in cells following a short-term exposure was detected by Comet Assay. However, this damage can be restored or undergo programmed cell death (apoptosis) and/or mutations, leading to a reduced detectable DNA damage [30] (Fig.6). Consequently, LDR does not contribute to the accumulation of DNA mutation and has no damaging effect on cell transformation, which may reflect in no change in cancer risks [31].

Based on the obtained data, an increase in TM and TL was found, which is related to chronic exposure to high natural radiation and considered as the criteria of DNA damage. Moreover, an elevation in the percentage of DNA in the tail that is directly proportional to the amount of damaged DNA was observed. This DNA damage was detected after continuous exposure to 10 $\& 20 \mathrm{mSv}$. Furthermore, this DNA damage occurred after simultaneous exposure to a dose of 2 Gy and a continuous dose of $10 \mathrm{mSv}$ from natural radiation. However, the results of simultaneous exposure to dose 2 Gy and $20 \mathrm{mSv}$ showed an improvement in the DNA damage. The radio-adaptive response means that a lowdose chronic natural radiation acts as an initial dose to stimulate in vivo radiation resistant. DNA damage induced by chronic exposure to $10 \& 20 \mathrm{mSv}$ and acute exposure to 2 Gy Gamma radiation using Comet assay showed an increase in all Comet assay parameters TL, TM, DNA in tail \& OTM after exposure. Chronic exposure to low dose from natural radiation showed a lower DNA damage when compared to the irradiated group with the challenge dose alone (2Gy). Adaptive response was significant at chronic exposure to $20 \mathrm{mSv}$; whereas it is not observed after $10 \mathrm{mSv}$. The induction of a radiation adaptive response in terms of DNA damage induced by chronic natural radiation exposure could be caused by enhanced level of antioxidative enzymes.

It can be said that the low dose radiation (LDR) does not only provide defense of DNA from immediate harmful events of DNA, but also contributes to the longterm adaptive reactions, which can protect the cell [32]. Several studies have shown that a single or fractionated $100 \mathrm{mGy}$ or alower dose of conditioning is enough to increase the development of DNA repair systems capable of safeguarding against DNA damage from challenge doses of 1 to 4 Gy [33-35]. These studies also show that fractional or chronic exposure of low dose radiation LDRs are more successful for developing and sustaining long-term adaptive responses than acute low dose radiation LDR exposure [36]. A number of studies have examined the function of priming dose (a) inducing antioxidants to detoxify free radicals from the higher challenging dose, (b) resulting in a pause in the cell cycle in the transient cell cycle affecting progression of cells, (c) rising apoptotic cell death, resulting in damaged cell loss and (d) activation of several signaling pathways. All of these aspects may be linked to radiation adaptation induction, which lead to DNA repair activation at a low-dose radiation [37]. It is known that a high dose radiation linked with cancer development. In contrast, there is no direct association between cause and effect at low radiation levels with a high degree of uncertainty [38]. A significant disadvantage of the linear non threshold model LNT is the non-compliance with DNA defense mechanisms. The LNT model is based on studies using DNA markers such as $\gamma \mathrm{H} 2 \mathrm{AX}$ for the identification of DNA. This makes it questionable that the repair of DNA is also linearly linked to the dose level of radiation [39-41]. This would mean the DNA repair mechanisms neutralize the DNA damaging effects induced by low dose radiation LDR. The LNT statement does not take the importance of biodefense systems into account, but implies that the risks of cancer at a zero dose starting point are proportionately linear without a threshold. The LNT presumption of low dose indicates that any radiation dose, irrespective of to what extent it is low, increases cancer risk [17]. The validity of using this dose response model is controversial as evidence that live species, including humans in the last decade, respond to a low dose radiation differently from a high dose radiation [42].

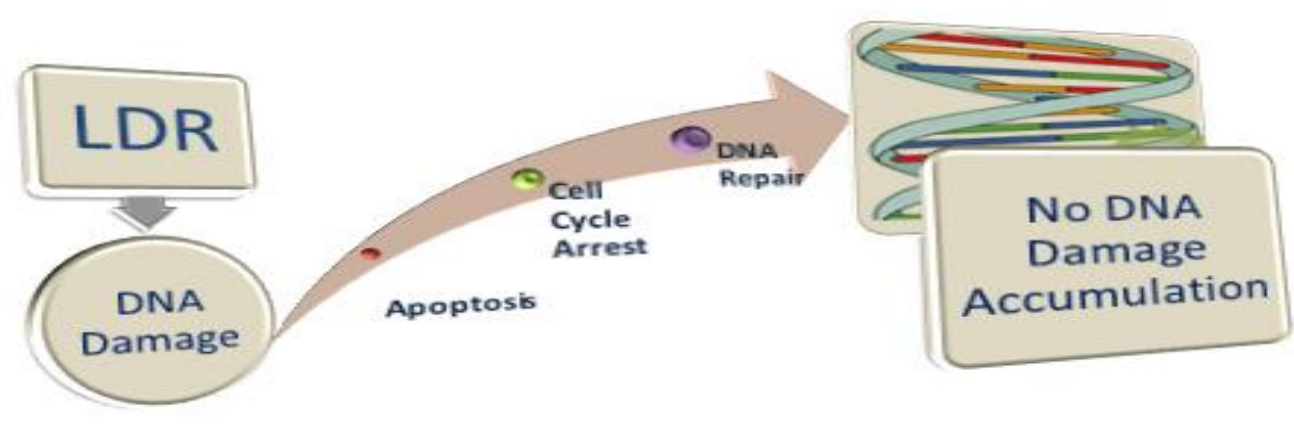

Fig. (6): Molecular mechanisms LDR exposed cells undergo preventing DNA mutation accumulation 
The ionizing radiation produces different reactive oxygen species (ROS) such as superoxide, hydrogen peroxide and hydroxyl radical, in a number of different cells. ROS is noticeably high reactive to cell macromolecule, including DNA, lipids and proteins. They are also engaged in cellular radiation reactions linked to signal transduction. Radiation affects genetic instabilities, which leads to a delayed biological effect such as gene mutation, chromosome aberration and cell death [43]. Cells respond to increased free radicals, by producing natural antioxidants including superoxide dismutase, glutathione, catalase that can diminish or eliminate cell structure damage. The glutathione peroxidase enzyme lowers ions of hydroxide, while superoxide dismutase decreased the superoxide ions to hydrogen peroxide. Catalase is used to generate water with hydrogen peroxide formed by superoxide dismutase $[44,45]$.The results of the present study showed a low production of antioxidant enzymes CAT, SOD \& GSH in chronic exposure to both $10 \& 20 \mathrm{mSv}$ and challange dose $2 \mathrm{~Gy}$. The exposure to $20 \mathrm{mSv}$ before $2 \mathrm{~Gy}$ gamma rays resulted in an enhancement of antioxidant enzymes accompanied with a decrease in free radicals, which represents an adaptive response. Eken et al. [46] has shown that occupational exposure to ionizing radiation can induce the activity of erythrocytes CuZn-SOD and Se-GPx enzymes, and diminish CAT enzyme and MDA activity. The findings can be explained in terms of radiation hormesis with low dose.

A high production of free radicals in chronic exposure (to both TE-NORM exposure for both 30 and 60 days, which is equivalent to $10 \& 20 \mathrm{mSv}$ respectively) and challenge dose 2 Gy using EPR was noticed in a previous work by the present authors [47]. These results are in line with what was obtained in the previous study as well, which confirms the damage of DNA as a result of chronic exposure to natural radioactive materials.

Finally, from the obtained results, it is clear that there is a balance between the DNA damage, which is measured by Comet assay and the internal defense system represented by the antioxidants, when being exposed to low radiation doses. It can be said that for low radiation doses, which are less than $100 \mathrm{mSv}$, their effects differ from high doses, so that it can be said that the body has an adaptive response and the application of the linear non-threshold model must be reviewed for these doses.

\section{CONCLUSION}

The preliminary results of the current study revealed that in vivo chronic low-level natural radiation provides an increase in the level of DNA damage and this damage can be balanced by internal defense system especially an increase in the antioxidant enzymes. At the same time, the chronic exposure to low level of natural radiation before challenge dose provides radio-adaptive response. Further studies will be needed to clarify the biological and health impacts of natural low-level chronic exposure to radiation.

\section{REFERENCES}

[1] Sohrabi, M. (1998) The state-of-the-art on worldwide studies in some environments with elevated naturally occurring radioactive materials (NORM). Appl. Radiat.Isot. 49, 169-188.

[2] Vinay, J., Vivek Kumar, P. R., Koya, P.K.M., Jaikrishan, G., Birajalaxmi Das (2016) Lack of increased DNA double-strand breaks in peripheral blood mononuclear cells of individuals from high level natural radiation areas of Kerala coast in India. Mutation Research, 788, 50-57.

[3] Shetty, P. K., Narayana, Y. (2010) Variation of radiation level and radionuclides enrichment in high background area. Journal of Environmental Radioactivivty, 101: 1043-1047.

[4] UNSCEAR (1993) Sources and effects of ionizing radiation.Report of the United Nations Scientific Committee on the Effects of Atomic Radiation to the general assembly. New York, USA: United Nations.

[5] Qureshi, A. A., Tariq, S. A., Ud Din. K., Calligaris, M. S. Waheed, A. (2014) Evaluation of excessive lifetime cancer risk due to natural radioactivity in the rivers sediments of Northern Pakistan. Journal of Radiation Research and Applied Sciences, 7(4): 438-447.

[6] Feinendegen, L. E., Paratzke, H. G., and Neumann, R. D. (2007) Damage propagation in complex biological systems following exposure to low doses of ionising radiation. Atoms for Peace: An International Journal, 1, 336-354.

[7] de Toledo, S. M., Azzam, E.I. (2006) Adaptive and bystander responses in human and rodent cell cultures exposed to low level ionizing radiation: the impact of linear energy transfer. DoseResponse, 4, 291-301. 
[8] Toprani, S.M., Das, B. (2015) Role of base excision repair genes and proteins in gamma-irradiated resting human peripheral blood mononuclear cells. Mutagenesis, 30, 247-261.

[9] Shadley, J. (1994) Chromosomal adaptive response in human lymphocytes. Radiat. Res. 138, S9-S12.

[10] Azzam, E.I., Raaphorst, G.P., Mitchel, R.E. (1994) Radiation induced adaptive response for protection against micronucleus formation and neoplastic transformation in $\mathrm{C} 3 \mathrm{H} 10 \mathrm{~T} 1 / 2$ mouse embryo cells. Radiation Research, 138, S28-S31.

[11] Hwang, S.L., Guo, H.R., Hsieh, W.A., Hwang, J.S., Lee, S.D., Tang, J.L., Chen, C.C., Chang, T.C., Wang, J.D., Chang, W.P. (2006) Cancer risks in a population with prolonged low dose-rate gammaradiation exposure in radiocontaminated buildings, 1983-2002. Int J RadiatBiol 82, 849-58.

[12] Hwang, S.L., Hwang, J.S., Yang, Y.T., Hsieh, W.A., Chang, T.C., Guo, H.R., Tsai, M.H., Tang, J.L., Lin, I.F., Chang, W.P. (2008) Estimates of relative risks for cancers in a population after prolonged low-dose-rate radiation exposure: a follow-up assessment from 1983 to 2005. Radiat Res 170,143-8.

[13] Doss, M. (2013) Linear no-threshold model vs. radiation hormesis. Dose Response 11, 480-497.

[14] Jolly, D., Meyer, J. (2009) A brief review of radiation hormesis. Australasian Physical \& Engineering Sciences in Medicine 32, 4.

[15] Stoilov, L.M., Mullenders, L.H., Darroudi, F., Natarajan, A.T. (2007) Adaptive response to DNA and chromosomal damage induced by X-rays in human blood lymphocytes. Mutagenesis 22(2), 117-122.

[16] Kant, K., Chauhan, R.P., Sharma, G.S. et al (2003) Hormesis in humans exposed to low-level ionizing radiation. International Journal of Low Radiation 1, 76-87.

[17] Desouky, O.S., Ding, N. and Zhou, G. (2015) Targeted and non-targeted effects of ionizing radiation. J. of Rad Res and ApplSci 8, 247 - 254.

[18] Landsberger, S. et al., (2013) Determination of 226Ra, 228Ra and210Pb in NORM products from oil and gas exploration: problems in activity underestimation due to the presence of metals and self-absorption of photons, J. Environ. Radioact., 125, 23-26.

[19] UNSCEAR (United Nations Scientific Committee on the effects of Atomic Radiation) (2000) Sources and Effects of Ionizing Radiation. Report to General Assembly. Exposures from natural radiation sources. Annex B, United Nations, New York.

[20] Singh, N.P., McCoy, M.T., Tice, R.R., Schneider, E.L. (1988) A simple technique for quantitation of lowlevels of DNA damage in individual cells. Exp. Cell Res. 175, 184-191.

[21] Jiang, B., Nie, J., Zhou, Z., Zhang, J., Tong, J., Cao, Y. (2012) Adaptive response in mice exposed to $900 \mathrm{MHz}$ radiofrequency fields: primary DNA damage. PLOS ONE 7, 32-40.

[22] Konca, K., Lankoff, A., Banasik, A., Lisowska, H., Kuszewski, T., Gozdz, S. Koza, Z., Wojcik, A. (2003) A cross platform public domain PC imageanalysis program for the Comet assay. Mutat Res 534, 15-20.

[23] Ahmed, A.E., Hussein, G.I., Loh, J-P, AbdelRahman, S.Z. (1991) Studies on the mechanism of haloacetonitrile induced gastrointestinal toxicity: interaction of dibromoacetonitrile with glutathione and glutathione-S-transferase in rats. $J$ BiochemToxicol 6, 115-121.

[24] Sinha, A.K. (1972) Colorimetric assay of catalase. Analytical Biochemistry 47, 389-394.

[25] Minami, M., and Yoshikawa, H. (1979) A simplified assay method of superoxide dismutase. Clin. Chem. Acta. 92,337

[26] Lowe, D.J., Herzog, M., Mosler, T., Cohen, H., Felton, S., Beli, P., Raj, K., Galanty, Y. Jackson, S.P. (2020) Chronic irradiation of human cells reduces histone levels and deregulates gene expression. Scientific Reports 10, 2200

[27] UNSCEAR (2010) Sources and Effects of Ionizing Radiation. Volume I: Sources: Report to the General Assembly, Scientific Annexes A and B. UNSCEAR 2008 Report. United Nations Scientific Committee on the Effects of Atomic Radiation. United Nations sales publication E.10.XI.3. United Nations, New York. 
[28] Hendry, J. H. et al (2009) Human exposure to high natural background radiation: what can it teach us about radiation risks? J. Radiol. Prot.29, A29-42,

[29] ICRP (2007) The 2007 Recommendations of the International Commission on Radiological Protection (ICRP publication 103), Ann ICRP 37, 2-4.

[30] Siew, S. S., Kauppinen, T., Kyyronen, P., Heikkila, P., Pukkala, E. (2012) Occupational Exposure to wood dust and formaldehyde and risk of nasal, nasopharyngeal, and lung cancer among Finnish men. Cancer Manag Res 4,223-32.

[31] E. Elmore, X.Y. Lao, R. Kapadia, E. Giedzinski, C. Limoli, J.L. Redpath, Low doses of very lowdose-rate low-LET radiation suppress radiationinduced neoplastic transformation in vitro and induce an adaptive response, Radiat. Res. 169 (3) (2008) 311-318.

[32] Taylor, K., Lemon, J.A., Boreham, D.R. (2014) Radiation-induced DNA damage and the relative biological effectiveness of 18F-FDG in wild-type mice, Mutagenesis 29 (4), 279-287.

[33] Blimkie, M.S., Fung, L.C., Petoukhov, E.S., Girard, C., Klokov, D. (2014) Repair of DNA doublestrand breaks is not modulated by low-dose gamma radiation in C57BL/6J mice, Radiat. Res. 181 (5), 548-559.

[34] Park, H.S., Seong, K.M., Kim, J.Y., Kim, C.S., Yang, K.H., Jin, Y.W., Nam, S.Y. (2013) Chronic low-dose radiation inhibits the cells death by cytotoxic high-dose radiation increasing the level of AKT and acinus proteins via NF-kappaB activation. Int. J. Radiat. Biol. 89 (5), 371-377.

[35] Zhao, Y., Zhong, R., Sun, L., Jia, J., Ma, S., Liu, X. (2015) Ionizing radiation-induced adaptive response in fibroblasts under both monolayer and 3-dimensional conditions, PloS One 10 (3), e0121289.

[36] Edin, N.J., Sandvik, J.A., Vollan, H.S., Reger, K., Gorlach, A., Pettersen, E.O. (2013) The role of nitric oxide radicals in removal of hyperradiosensitivity by priming irradiation, J. Radiat. Res. 54 (6), 1015-1028.

[37] Vivek Kumar, P.R., Seshadri, M., Jaikrishan, G., Birajalaxmi Das, (2015) Effect of chronic low dose natural radiation in human peripheralblood mononuclear cells: Evaluation of DNA damage and repair usingthe alkaline Comet assay. Mutation Research 775, 59-65

[38] Desouky, O.S., Morsi, T. and El-Marakby, S.M. (2021) Evaluating the Radiological Hazards of Contaminated Soil with Naturally Occurring Radioactive Materials (NORM) Resulting from Produced Water during Oil \& Gas Production. Arab J. Nucl. Sci. Appl., 54 (1), 162-172

[39] Bannister, L.A., Serran, M.L., Mantha, R.R. (2015) Low-dose gamma radiation does not induce an adaptive response for micronucleus induction in mouse splenocytes. Radiat. Res. 184 (5) 533-544.

[40] Cho, Y.H., Kim, S.Y., Woo, H.D., Kim, Y.J., Ha, S.W., Chung, H.W. (2015) Delayed numerical chromosome aberrations in human fibroblasts by low dose of radiation, Int. J. Environ. Res. Publ. Health 12(12), 15162-15172.

[41] Durdik, M., Kosik, P., Gursky, J., Vokalova, L., Markova, E., Belyaev, I., (2015) Imaging flow cytometry as a sensitive tool to detect low-doseinduced DNA damage by analyzing 53BP1 and gamma H2AX foci in human lymphocytes, Cytometry. Part A: J. Int. Soc. Anal. Cytol. 87(12), 1070-1078.

[42] Waldren, C. A. (2004). Classical radiation biology dogma, bystander effects and paradigm shift. Human \& Experimental Toxicology, 23, 95-100.

[43] Tominaga, H., Kodama, S., Matsuda, N., Suzuki, K., Watanabe, M. (2004) Involvement of reactive oxygen species (ROS) in the induction of genetic instability by radiation. J Radiat Res 45,181-188.

[44] Smith, T.A., Kirkpatrick, D.R., Smith, S. et al (2017) Radioprotective agents to prevent cellular damage due to ionizing radiation. $J$ Transl Med 15, 232.

[45] Holley, A. K., Miao, L., St Clair, D.K., St Clair, W.H. (2014) Redox-modulated phenomena and radiation therapy: the central role of superoxide dismutases. Antioxid Redox Signal 20(10),156789.

[46] Eken, A. et al (2012) Induced antioxidant activity in hospital staff occupationally exposed to ionizing radiation. Int. J. Radiat. Biol 88, 648-653. 
[47] El-Marakby, S.M., Awad, M.M., Eraba, K.M., Abdelgawad, M.H., Desouky, O.S. (2020) Assessment of chronic exposure effects and radioadaptive response of natural occurring radioactive materials (NORM). Radiation Physics and Chemistry 166,108502. 